\title{
MICROTEACHING AS A METHOD OF TEACHING PROFESSIONAL SKILLS FOR PRE-SERVICE LANGUAGE TEACHERS (ON THE EXAMPLE OF PROFESSIONAL COURSE FOR BACHELOR STUDENTS)
}

\author{
V.A. Skakunova \\ Lomonosov Moscow State University, Moscow, Russian Federation, \\ victoria.skakunova@yandex.ru
}

\begin{abstract}
Microteaching is considered a teaching technique and treated as an effective one due to its simplicity in performance and its reliability in case of control of acquired teaching skills among novice or pre-service teachers. Integration of information and communication technologies in language teaching leads to rethinking a teacher's role in a classroom as well as their functions and competencies in the light of contemporary educational system.

The aim of the article is to present theoretical basis of microteaching as a teaching technique, to reveal the peculiarities of using microteaching in teaching pre-service teachers, Bachelor students, so as to help students develop necessary skills of integration of information and communication technologies in learning environment.

To conduct the research the author used such methods as comparative one so as to compare different theoretical statements laid in the basis of microteaching technique. Moreover, empirical methods helped to choose the strategy suitable for the target audience. Also, the synthesis is used to observe and analyze the study and find out some peculiarities in using microteaching in professional education.

As a result, the author elaborated a new model of microteaching.

Originality of the article is explained by the fact that for the first time microteaching was used as a teaching strategy in professional skills' development. Moreover, the technique originated by foreign scholars was enriched with Russian didactics' achievements for lesson planning.

As for the practical application double positive effect was observed during the study. On the one hand, students acquired necessary teaching skills and competences, on the other hand, expert teachers observed microteaching efficiency.

Keywords: microteaching, professional education, pre-service language teachers, ICT in teaching, teacher training, information and communication technologies.
\end{abstract}

\section{Introduction}

Originally microteaching was invented by Dwight Allen at Stanford University in the 1970s as a training technique. Since then, it has been applied in different universities and different programs as an effective teaching technique to help to acquire new professional skills in a more practical way. Behaviourism as psychological theory is on the basis of microteaching. Even though some authors consider that microteaching has borrowed a lot from humanistic approach [15] as well.

Microteaching is defined as a training technique in which pedagogical context is simplified and structurized where teacher trainees focus on and master "one one particular aspect of a lesson of teaching technique" [14]. Its purpose is to simplify and systematize a complex teaching- learning process so as to help pre-service teachers to be aware of its peculiarities and be prepared.

The aim of the study is to present the results of the research devoted to using microteaching as an optimal training technique while teaching pre-service teacher to integrate information and communication technologies in language teaching process.

Originality of the considered study is determined by the issue of integrating information and communication technologies in educational process and, as a result, by acquiring teaching skills necessary for conducting a lesson with the use of new technologies and according to educational standards.

\section{Literature review}

Microteaching created at Stanford University has become a highly popular training technique 


\section{Теория и методика профессионального образования}

used in many other on-campus contexts and in the majority of teacher training programs [5, p. 89] to help teachers master skills needed for teaching. The original stages of microteaching that were elaborated at Stanford University are "plan, teach, observe, re-plan, re-teach and re-observe". However, nowadays many variations of it have spread among different educational organizations. Thus, microteaching may be realized in solely «artificial» environment or be presented in natural classroom environment [1, p. 117]. Nonetheless, it should be noted that according to some foreign researchers and practitioners $[2,3$, $12,13]$ some components are supposed to be essential in any microteaching variation - videotaped lessons and feedback from peers and from a teacher trainer.

Moreover, it should be pointed out that one element that remains in any variations is feedback after the microteaching - oral, written or both - provided by the expert, teacher trainer.

As far as positive effect of microteaching is concerned, Wahba [18, p. 22] believes that microteaching is able to facilitate teaching practice for novice teachers by minimizing situations of failure. Furthermore, he presented four stages of microteaching: (1) trainees are provided with materials on teaching skills that are going to be taught; (2) during next session trainees present their micro-lesson and (3) then, the micro-lesson is analyzed and discussed by peers or/and teacher trainer, in other words, trainees receive feedback; (4) afterwards, trainees re-teach their lesson. This kind of teaching applied in many disciplines as well as in mathematics where Fernandez [7, p. 354] identified growth in teaching knowledge of teacher-students, especially while debating and providing with adequate and needed feedback. In this sense, use of microteaching for medical teacher students has been also perceived as effective one due to its divisions of the whole process into several ones so as to facilitate efficient performance [16]. Some authors focus on teacher identity and its changes during microteaching process and identified that this kind of teaching brings positive impact on teacher's development and their identity [11]. Furthermore, with the help of feedback provided by peers and/or by an expert microteaching could lead not only to improvement in teaching techniques and performance but also in better understanding of a target audience, learners [9].

Nevertheless, there are some critics that emphasize the artificial nature of microteaching.
Such disadvantages as non-natural environments [17, p. 4], limited time to prepare a lesson for microteaching [8].

\section{Microteaching Definition}

Microteaching has been originally used as a teaching technique in higher education since 1970s. It can be identified as "performance during which practitioners teach short lessons to small groups of learners and ... receive some kind of feedback" [15]. The essence of the this method could be identified as a possibility to divide a complex educational process into several parts so as to better understand how the whole process works and to facilitate pre-service teachers' integration into teaching environment or to help experts to master their professional skills.

Moreover, there exist some other advantages of using this method. The presence of feedback in the structure of microteaching leads not only to improving skills during the process of "feedbackre-teach" but also to socializing of teachers [10, p. 19]. Finally, the time attributed to one microteaching presentation to small groups is usually no more than 15-20 minutes [6].

\section{Research Methodology}

The present study was aimed at analyzing the effectiveness of implementing of microteaching technique into educational process while teaching students to properly apply information and communication technologies (ICT) in foreign language teaching.

As far as research design is concerned it should be noted that the study was realized during the course of "ICT in Linguodidactics". The course comprised two parts - theoretical and practical. Theoretical one was devoted to different aspects of implementing ICT into teaching; the second part involved practical aspect - several ICT elected by teachers were taught to students. Practical part of this course will be the object of the considered study. The educational process was divided into several parts and that was determined by the expected result of the learning process. The expected result was acquiring of professional skills of using ICT in language teaching context.

The target audience included students of $2^{\text {nd }}$ and $4^{\text {th }}$ year Bachelorstudents of Language Teacher Specialization at the Faculty of Foreign Languages and Area Studies at Lomonossov Moscow State University. All in all, 60 students participated in this course. It should be mentioned that the course is obligatory as it is an important part of specialization set of disciplines. As the course was aimed at teaching pre-service 
teachers to integrate information and communication technologies in language teaching, all students learn at least two modern languages. In this respect, all of them were potentially interested in acquiring new teaching skills and knowledge.

The course was of one academic semester. Practical part took 14 weeks. Each week was devoted to one or several helpful information and communication technology (ICT) in teaching. It means that students were studying one ICT in terms of its technological characteristics and then, didactic potential while integrating it in learning environment. This process was a scrupulous one for all participants of the course. The whole methodology and practice outcomes were posted on Wiki so as Bachelor students could find to necessary information as well as to follow their progress anytime during the course acquisition. Each week students had to accomplish some task main objectiveof which was to verify their acquisition of the given information and to practice their skills so as to develop teaching competences on technological and didactic levels.

After creating their micro-lesson, students posted links to them on the site so that everyone could see and leave their constructive feedback. Some of the lessons were examined and discussed with a teacher trainer's feedback during the next classes. This strategy helped students to get acquainted of what pitfalls they needed to avoid and how to create a worthwhile lesson.

The whole of process of practical part was systematized, structured and cyclic and met requirements of general scheme of microteaching though modified according to circumstances. So modified 'formula' of microteaching used in this study included the following aspects 'learnpractice-feedback-re-teach'.

\section{Results}

The results of the study were presented in questionnaires collected from students before and after the study. Then, they were compared and analyzed in terms of efficiency of the course.

Among close-ended questions in the precourse questionnaires there were such questions as following ones:

(1) Do you teach at some institute or give some private classes?

(2) Do you agree that ICT-competency is important for a language teacher?

(3) Do you think this course is an essential part of language teacher's professional preparation?
As for the first question more than a half of students $(58 \%)$ were engaged in teaching so they had some teaching experience and could understand faster how to integrate ICT in the classroom. Answers to the second question demonstrated that $91 \%$ of students agree that ICTcompetency is important for professional education of a teacher. Finally, answer to the third question outlined that $83 \%$ of Bachelors consider this course to be one of prior ones in their professional development. All these data proved that the course is needed and the results would be fruitful for the students and for the research as well.

According to the post-course questionnaire $93 \%$ of participants found that the course was efficient in terms of professional development. Moreover, the majority of students (95\%) appreciated the selection of ICT studied during the course - thus, the work of expert teachers was effective. In addition, there was a question related to the usage of microteaching during study "Was microteaching as a chosen teaching strategy effective for you in this course?" - $94 \%$ of students answered in a positive way. At the end of the questionnaire students were supposed to answer one crucial question: "Are you going to use ICT in teaching the future?" The answers of $95 \%$ of students were positive.

\section{Discussion}

Findings received from the research indicate that microteaching was rightly chosen by expert teachers. Moreover, according to the results of post-course questionnaires Bachelor students also found microteaching an effective technique in their professional development.

However, as many authors underline microteaching has its own drawbacks expressed mostly in its artificial nature. In other words, participants don't always feel totally involved in studying process as the situations they are working at are not real for them. It should be noted that while conducting this research and expert teachers notice that $20 \%$ of students showed such attitude. Nevertheless, most of students were aimed at studying various ICT and create lessons with studied ICT. Even discussion of lessons were natural - it means feedback provided by groupmates didn't seem unnatural. Perhaps, that was due to students' absence or lack of sufficient experience.

\section{Conclusion}

As microteaching as relatively new technique is used in the study devoted to teaching Bachelor students, pre-service language teachers 


\section{Теория и методика профессионального образования}

to implement information and communication technologies in learning environment. Novelty of the considered study is determined by arising issue of integrating information and communication technologies in educational process and, as a result, by acquiring necessary teaching skills for conducting a lesson with the use of new technologies and according to educational standards.

\section{References}

1. Amobi F.A. Preservice Teachers' Reflectivity on the Sequence and Consequences of Teaching Actions in a Microteaching Experience. Teacher Education Quarterly, 2005, iss.Winter, pp. 115-130.

2. Benton-Kupper J. The Microteaching Experience: Student Perspective. Education, 2011, no. 121, pp. $830-835$.

3. Brent R., Wheatley E.A., Thomson W.S. Videotaped Microteaching: Bridging the Gap from the University to the Classroom. The Teacher Educator, 1996, no. 31, pp. 238-247. DOI: 10.1080/08878739609555115

4. Cripwell K., Geddes M. The Development of Organizational Skills through Microteaching. ELT Journal, 1986, no. 36(4), pp. 232-236. DOI: $10.1093 /$ elt/36.4.232

5. Cruickshank D.R., Metcalf K.K. Improving Preservice Teacher Assessment through On-campus Laboratory Experiences. Theory into Practice, 1993, no. 32, pp. 86-92. DOI: 10.1080/00405849309543580

6. Fernández M.L. Learning through Microteaching Lesson Study in Teacher Preparation. Action in Teacher Education, 2005, no. 26, pp. 37-47. DOI: 10.1080/01626620.2005.10463341

7. Fernández M.L. Investigating how and what Prospective Teachers Learn through Microteaching Lesson Study. Teaching and Teacher Education, 2010, no. 26(2), pp.351-362. DOI: $10.1016 /$ j.tate.2009.09.012

8. Lederman N., Gess-Newsome J. Metamorphosis, Capturing Complexity: A Typology of Reflective Adaptation, or Evolution? Pre- service Science Teachers' Concerns and Perceptions of Teaching and Planning. Science Teacher Education, 1991, no. 75(4), pp. 443-456. DOI: 10.1002/sce.3730750406

9. Legutke M., Schocker-v Ditfurth M. School-based Experience. The Cambridge Guide to Second Language Teacher Education. New York, Cambridge University Press Publ., 2009, pp. 209-217.

10. Lortie D. Schoolteacher: A Sociological Study. Chicago, University of Chicago Press Publ., 1975. 308 p.

11. Mergler A.G., Tangen D. Using Microteaching to Enhance Teacher Efficacy in Pre-service Teachers. Teaching Education, 2010, no. 21 (2), pp. 199-210. DOI: 10.1080/10476210902998466

12. Metcalf K.K. Critical Factors in Oncampus Clinical Experience. Teaching Education, 1993, no. 5, pp.164-174.

13. Mills R.F. Micro-teaching: Organisation and Benefits. Education, 1991, no. 111, pp. 559-562.

14. Morrison B.Teacher Training in China and the Role of Teaching Practice. Available at: http://sunzil.lib.hku.hk/hkj/view/45/4500089/pdf (accessed 2.05.2017)

15. Perlberg A. Microteaching - Present and Future Directions. Educational Media International, 1976, no. 13(2), pp. 13-20. DOI: 10.1080/09523987608548869

16. Remesh A. Microteaching, and Effective Technique for Learning Effective Teaching. Journal Research in Medical Sciences, 2013, no. 18 (2), pp.158-163.

17. Stanley C.A Framework for Teacher Reflectivity. TESOL Quarterly, 1998, no. 32(2), pp. 584-591. DOI: $10.2307 / 3588129$

18. Wahba E. Microteaching. English Teaching Forum, 1999, no. 37(4), pp. 22-23.

19. Zeichner K., Tabachnick B.R. Are the Effects of University Teacher Education Washed out by School Experiences? Journal of Teacher Education, 1981, no. 32, pp.7-11. DOI: $10.1177 / 002248718103200302$

Received 18 April 2017 


\title{
МИКРООБУЧЕНИЕ КАК МЕТОД ОВЛАДЕНИЯ ПРОФЕССИОНАЛЬНЫМИ НАВЫКАМИ ДЛЯ БУДУЩИХ УЧИТЕЛЕЙ ИНОСТРАННОГО ЯЗЫКА (НА ПРИМЕРЕ ПРОФЕССИОНАЛЬНОГО КУРСА ДЛЯ СТУДЕНТОВ-БАКАЛАВРОВ)
}

\author{
В.А. Скакунова \\ МГУ имени М.В. Ломоносова, г. Москва
}

\begin{abstract}
Микрообучение - это обучающая технология, которая рассматривается как одна из эффективных, благодаря простоте в реализации и фактору надежности в ситуации контроля полученных профессиональных навыков будущих и начинающих учителей иностранного языка. Интеграция информационно-коммуникационных технологий в преподавание иностранных языков приводит к пересмотру роли учителя на занятии и его профессиональных функций и компетентностей в свете современной образовательной парадигмы.

Целью статьи является представить теоретические основы микрообучения как обучающей технологии, выявить особенности использования данной технологии в обучении будущих учителей, студентов-бакалавров, чтобы помочь студентам развить необходимые навыки и умения интеграции информационно-коммуникационных технологий в обучающую среду.

Для проведения данного исследования был использован сравнительный метод с целью сравнения различных теоретических утверждений о технологии микрообучения. Эмпирические методы помогли выбрать правильную стратегию в обучении конкретной целевой аудитории. Методы анализа и синтеза внесли вклад в обзор и анализ исследования и помогли обозначить особенности использования микрообучения в профессиональном образовании.

Новизна статьи объясняется тем фактом, что микрообучение было впервые применено для формирования профессиональных навыков в преподавательской среде. К тому же данная обучающая технология, изначально созданная за рубежом, была адаптирована к российской современной образовательной действительности на основе достижений отечественной дидактики с целью использования при создании урока.

Во время проведения научного исследования выявились два позитивных аспекта практического применения данной педагогической технологии - во-первых, студенты приобрели умения и компетенции, необходимые для ведения преподавательской деятельности. Во-вторых, преподаватели, обучающие студентов, имеют возможность наблюдать за эффективностью применения микрообучения.

Ключевые слова: микрообучение, профессиональное обучение, будущие учителя иностранного языка, ИКТ в преподавании, обучение учителей, информационно-коммуникациионные технологии.
\end{abstract}

Скакунова Виктория Александровна, преподаватель кафедры лингвистики и информационных технологий факультета иностранных языков и регионоведения МГУ имени М.В. Ломоносова, г. Москва, victoria.skakunova@yandex.ru.

Поступила в редакцию 18 апреля 20172.

\section{ОБРАЗЕЦ ЦИТИРОВАНИЯ}

Skakunova, V.A. Microteaching as a Method of Teaching Professional Skills for Pre-Service Language Teachers (on the Example of Professional Course for Bachelor Students) / V.A. Skakunova // Вестник ЮУрГУ. Серия «Образование. Педагогические науки». - 2017. T. 9, № 3. - C. 97-101. DOI: 10.14529/ped170310

\section{FOR CITATION}

Skakunova V.A. Microteaching as a Method of Teaching Professional Skills for Pre-Service Language Teachers (on the Example of Professional Course for Bachelor Students). Bulletin of the South Ural State University. Ser. Education. Educational Sciences. 2017, vol. 9, no. 3, pp. 97-101. DOI: 10.14529/ped170310 